\title{
10 \\ Touristic Encounters: Imag(in)ing Tahiti and Its Performing Arts
}

\author{
Jane Freeman Moulin
}

The twenty-first century has brought a palpable, new omnipresence of tourism to French Polynesia - as the focus of government hopes for an economic engine to ease the current monetary woes of the country and as a subject that touches the daily lives of island residents. Of vital economic importance to Pacific Island nations, tourism is also of core interest to scholars in a range of academic disciplines, including ethnomusicologists who view touristic presentations involving performative arts as culturespecific displays of social/economic/artistic interactions rendered audible and visible. Despite the long-established use of Pacific music and dance in the presentation of culture for outsiders, however, relatively few scholars (and even fewer ethnomusicologists and dance ethnologists) have turned an analytical eye to the confluence of tourism and Pacific dance. ${ }^{1}$ In particular, a performer's viewpoint of how tourism affects artistic performance or its participants is minimal or noticeably missing. Larsen and Urry state that "the tourist gaze is "mutual", where the eyes of gazers

1 See Alexeyeff (2009), Balme (1998), Condevaux (2011), Connell and Gibson (2008), Desmond (1997, 1999), Dick (2014), Hayward (2001), Imada (2011, 2012), Kaeppler (1977), Kahn (2011a, 2011b), Kole (2010), Senft (1999), Stillman (1988), Tatar (1987), and Waitt and Duffy (2010). 
and gazees intersect' (2011:1118); ${ }^{2}$ however, Bunten notes the externality of tourism research in her examination of the 'commodified self' from her perspective of working as a Native American guide.

Ironically, few anthropologists who look at issues surrounding cultural tourism have been able to successfully work inside the industry (other than in the role of 'the hired anthropologist') ... their research is more often focused on the experience of the tourist than on that of the cultural producer. (Bunten 2008: 382)

Similarly, research has focused on the web of social/political/economic issues surrounding Pacific touristic presentations, with little attention paid to details of the content or the artistic decisions involved in the encounter between tourists and musicians/dancers through the shared spaces of performance. Speaking of music experienced through dance, Saldanha argues that it shapes social realities as an interplay of sound, embodiment, space, and politics' (2005: 719). To understand the tourism of performance then, we must recognise the players and their experiences in this intricate visitor-host convergence.

Music and dance are essential to creating an identifiable niche for Tahiti within the global marketplace. This chapter examines how Tahiti markets ideas of distinction and turns the ephemeral arts of performance into tangible experience-promoting and delivering artistic culture as part of the overall production of tourism. Purposely keeping analysis tightly on the art itself, I endeavour to reach past problems associated with the tourist 'gaze' (Urry 1990), 'object authenticity' (Wang 1999), and 'staged authenticity' (MacCannell 1973) to 'disrupt the reductive analyses that cast locals and tourists as unwilling puppets performing a gaudy dance on the fingertips of some nebulously conceived "tourism industry" (Taylor 2010: 37). Heeding Taylor's challenge to approaches that 'reduce and essentialize cultural tourist events as well as the performers therein, as simple indexes of touristic desires' (ibid.), I view performers as primary agents in the waltz of cultural encounter. With 'encounter', I signal a move beyond the passive 'gaze' to explore cultural interactivity as a dynamic realm with promise for understanding how Tahitian artists exercise their power and for unravelling the entangled relationships between performer and viewer.

2 See also Maoz (2006). 
In taking this approach, I do not provide a history of travel to Tahiti or chronicle French Polynesian dependency on tourism; others have done this very capably. ${ }^{3}$ I invoke tourism practices elsewhere in comparison, often referring especially to Hawai' $i$ as the Pacific's extreme example of mass tourism development and the cradle for many of the ongoing stereotypes that get transferred to Tahiti, but I do not expand overall analysis to encompass these other destinations. Rather than tossing a wide net, I focus on touristic presentation and the reality of performance in the lived space of the Tahitian artistic community in an effort to capture sites where this alignment might escape the consideration of other disciplines and perspectives. Eschewing an often voyeuristic stance, I prefer to poke at those spaces where dancers and musicians, as dynamic agents in the act of encounter, use tourism to help achieve their needs and goals as artistsspaces where they become players invested in culture rather than cultural detractors who undermine it through tourist performances. Turning an ethnomusicological lens to the details of programming, repertoire, performance practice, costuming, and movement, I re-centre the artistic elements of the encounter to expand the interpretive position of the general culture analyst. Research has underscored the need to revisit tourism as a performed, embodied, multisensory realm (Connell and Gibson 2008; Gibson 2010; Larsen and Urry 2011; Saldanha 2005; Waitt and Duffy 2010). Tahitian dance presentations offer an optimal vehicle for doing so.

I propose that dance in Tahiti contrasts with that of other highly developed tourist destinations, arguing that Tahitian performances counter notions of tourist art as devalued presentation. Rather than viewing Tahiti's touristic performances as cultural loss, ${ }^{4}$ I contemplate the role touristification plays in contributing to cultural sustainability through the arts and examine tourism-not as passive artistic victimisation-but as a space where Tahitians display their current views of their culture, maintain agency in the presentation of that culture, and serve as active representatives in developing it. Taking a cue from Edward Bruner's view of touristic enactments as genuine social performances (2005: 5), I explore music and dance as real events where tourists have an opportunity to engage with locals in and through performance.

3 Kahn's excellent book (2011a) provides a broad background of tourism development in Tahiti, detailing its ties to the power relations of space, colonisation, nuclear experimentation, and image creation.

4 Desmond, speaking of performance in Hawai' $i$, employs the descriptor 'staged authenticity' (1999: xix), while Kaeppler (1977) uses 'airport art' for Pacific tourist performances. 
I first present Tahiti's current pro-tourism stance and then examine how Tahiti markets difference and transfers touristic goals into tangible experiences. Given the long history of outsider interaction with the Pacific, I address entanglements resulting from persistent South Seas stereotypes developed over the centuries and explore tropes that frame the interactions of tourism, especially the sexualisation of Tahitian women. Seeking to unpack the snarled areas of this frame, I present a performer's view of the actions, thoughts, and values that comprise performance and demonstrate their alignment with artistic practice in the local community. In doing so, I draw on years in Tahiti's tourism industry, experience as a professional dancer in two of Tahiti's foremost traditional dance groups, and ongoing return fieldwork. ${ }^{5}$ Rather than seeing dance as isolated from Tahitian life in what Kahn refers to as the 'cocoon' of tourism (2011a: 127-54), I see performance as something that links those worlds. My comments here apply specifically to Tahiti, only one of 118 islands in French Polynesia. Aware that situations of tourist performance are different on other islands, I focus on Tahiti because of its developed tourism sector, greater number of professional dance troupes, and numerous hotel performances.

Tahitians view music and dance as inseparable arts—one does not dance without music, dancers are singers in performance, and tight dancermusician communication underlies all presentations. While music in dance shows may appear secondary to the visuality of movement, this belies the fact that the music dictates everything. In Tahiti, dance is not merely a visual spectacle; it is a richly sensory event combining visual, auditory, and olfactory sensations to create an exciting and embodied multidimensional performance. ${ }^{6}$

5 Fieldwork in Tahiti includes extended residence (1973-77), a six-month research stay (2006), and repeated three-month return trips $(1985,1989,1995,1998,2000$, and 2012), with a shorter trip in 2009. In the 1970s, I worked in both the office and the tourist buses of Agence Tahiti Nui Travel and danced regularly three nights a week at the Maeva Beach Hotel and the Travelodge (Intercontinental Hotel), with Coco Hotahota's Temaeva troupe (1973-74) and Paulette Vienot's Tahiti Nui (1974-76). I joined the touring company of Tahiti Nui, the Royal Tahitian Dancers, for its international tour to Peru and Chile (1974) and performed in the annual Tiurai dance competitions (today, Heiva i Tahiti) with Temaeva $(1974,1976)$ and Tahiti Nui (1975). More recently, I was a cultural lecturer on the cruise ship Aranui (2000) and a member of the prize-winning singing group from the district of Papara for the Heiva competition $(2006,2012)$. My connection to tourism in Hawai $i$ is as a violinist in Don Ho's orchestra (September 1968 - June 1969), and as a professor of ethnomusicology (University of Hawaii-Mānoa) who trains Tahitian dancers, several of whom have subsequently danced for tourist shows in Hawai i $i$.

6 Olfactory sensation, overlooked and negated in Western dance, is a prominent part of Polynesian dance traditions. See Moulin (2013) for a detailed look at this aspect of performance in the Marquesas Islands. 


\section{A pro-tourism stance: Imag(in)ing Tahiti}

Tourism in French Polynesia is a relatively young industry. Tahiti entered the world of organised modern travel in 1960 with the opening of a new airport near the capital of Pape'ete. The airport offered expanded links to the world, a promise belying the primary motivation for its constructionto provide the infrastructure to transport equipment and personnel for France's yet unannounced nuclear experimentation in the Pacific - and diverting attention from plans to turn the territory into a nuclear test site (Henningham 1992: 127; Kahn 2000: 13-14, 2011 a: 69-73). Under the social and environmental fallout of nuclear testing, ${ }^{7}$ tourism's modest beginnings expanded quickly to include additional hotels, travel agencies, an official tourism office, an extensive runway construction programme reaching the farthest islands of the territory, ${ }^{8}$ and ancillary businesses servicing the new industry. With a 55-year history, tourism today is a normalised feature of island life for two generations of Tahitians.

During fieldwork in 2006 and 2012, however, I noticed something palpably different: conversations formerly among those in the industry were now part of the daily discourse of a more generalised population. Tourism was the buzzword in newspapers and on television, coming up frequently in casual conversations in comments underscoring various malaises of Tahitian life, as in: 'All these stray dogs-that's not good for tourism' or 'Concrete walls that block views of the sea-not good for tourism' or 'The stench of garbage and sewage around the airportdefinitely not good for welcoming visitors'. Tahiti clearly had tourism on its mind.

7 Atmospheric testing began in 1966 on Moruroa and Fangataufa, about 1,250 kilometres from Tahiti. Moving underground in 1974, tests continued until 1996 amid strong and occasionally violent local and international protest (Danielsson 1988; Henningham 1992; Kahn 2011a).

8 French Polynesia constructed 31 runways during the two decades following the opening of the airport (Air Tahiti n.d.), creating secondary markets on islands and atolls much less developed than Tahiti and spreading tourism's reach across the Society Islands to the atolls of the Tuamotu Islands. 
Tourism is not an uncontested zone, however. Not all people have favoured an influx of visitors, and, indeed, some communities stand firm against specific development projects. ${ }^{9}$ The government's positive framing of the industry that I observed in 2006-12, however, was in response to several factors, including the end of nuclear experimentation (1996) with loss of its accompanying job creation and influx of money, a drop in tourism after the September 11 tragedy, weakening global markets for copra and vanilla, a 95 per cent price drop in the pearl-culture section due to overproduction (IRD 2012), and a tightening of the French colonial purse strings-all leaving many Tahitians apprehensive about their economic future. There is a need to diversify an island nation reliant on black pearls, coconut products, noni fruit (Morinda citrifolia), and vanilla; many look to tourism as the cure-all and future of Tahiti. ${ }^{10}$ Tourism has become both a dreamed-of remedy for colonial economic woes andas seen with problems concerning dogs, garbage, and diminishing views of the sea-a voice to motivate governmental action that benefits Tahitians as well. Apparent in all of this is that Tahitians are also questioning the very image they offer to travellers.

Image is key to the tourism industry. Tourists are offered selective portraits of potential world destinations, snapshots representing a legacy of complex host/visitor relations. For Tahiti, this legacy stretches back to the eighteenth-century journals of Captain Cook and other European explorers that aroused the curiosity and fascination of the continental world. Volumes have been written about these early impressions; my aim here is only to emphasise key elements as background information.

9 In the early 1990s, a planned hotel in Puna'auia on the island of Tahiti prompted active protests because of its proposed site on an ancient burial ground. After four years of protestor occupation and the eventual mobilisation of the French gendarmes (1996), the Méridien finally opened in 1998 (Stanley 2004: 183). There are also well-known examples of individual families resisting attempts to renew tourist-hotel leases or to allow new construction (Bachimon 2012) and cases of activism on the outer islands when residents found a particular project, such as a water park, incompatible with their ideas of appropriate development (Kahn 2000: 11;2011a).

10 The lure of tourism continues despite failure to realise the large growth potential envisioned by the government. Notwithstanding its famous name and centuries of appeal to the outside world, Tahiti has a relatively small tourist industry, welcoming only 150,000-200,000 visitors per year (Bachimon 2012). To contrast this with another Pacific destination, Tahiti had 168,978 visitors in 2012; Hawai'i recorded 8,028,744 that same year (Hawai'i Tourism Authority 2012: 2). Even with a gentle increase in visitors over recent years, the number of tourists travelling to Tahiti in 2014 was only 180,602 , well below the 2007 level of 218,241 (ISPF 2015a). 
Referencing Cythera, the Aegean island sacred to Aphrodite, and exciting European imaginations on levels that were explicitly feminised and sexualised, one representative account states:

This may well be called the Cytheria $[s i c]$ of the southern hemisphere, not only for the beauty and elegance of the women, but their being so deeply versed in, and so passionately fond of the Eleusinian mysteries ... where the earth without tillage produces both food and cloathing $[s i c]$, the trees loaded with the richest of fruit, the carpet of nature spread with the most odiferous flowers, and the fair ones ever willing to fill our arms with love. (Hamilton 1793: 37)

Beautiful women, an eternal welcome, sexual liberty, an easy life-Tahiti encapsulated a vision that reverberated over the centuries with tenacious fidelity to the same underlying theme. Underscoring how Europeans perceived artistic expressions of these Islanders through very different eyes, Smith states: 'The only native art that gained wide attention from Europeans from the beginning was the dance, for the dances were interpreted not as evidence of native artistry but of savage freedom' (1985: 123). Balme addresses notions of artistic incongruity:

The Polynesian practice of theatricalizing sex, [and] ... framing it within a formalized performance situation - through dance, music and spatial arrangements-posed a genuine challenge for Western conceptual categories ... What remained invisible were the performative structures and transactions enacted on the indigenous side of the cross-cultural encounters ... (Balme 2007: 45-46)

The incommensurability of dance-combined with the Cytherian trope-continued throughout the nineteenth century, as the image of Tahiti spread around the world, developing deep roots through the very repetition and persistence of the imaginings. A rich ethnographic iconography supported verbal descriptions, with Polynesian dances 'easily one of the most popular motifs' (ibid.: 40). Artistic portrayals of Islanders and island life continued to enliven European fantasies, with paintings created by Gauguin for the 1890s art world (already outof-date nostalgic reveries in his own time) ${ }^{11}$ becoming more realistic photographs of bare-breasted women for twentieth-century travel books

11 Not finding Tahiti the island of his dreams, Gauguin left in 1901 to pursue 'his life-long quest for an unspoilt, primitive island', moving to the Marquesas Islands, where he died in 1903 (Danielsson and Danielsson 1973: 22). 
and postcards (Figures 1 and 2). ${ }^{12}$ In America, imaginings of Tahitian women were augmented by the racialised and gendered grass-skirted 'hula girl' stereotype emerging from Hawai' $i$, portrayals that Desmond (1999) discusses in detail and that Imada $(2011,2012)$ traces back to the international expositions, vaudeville shows, and other entertainment venues of 1890s American popular culture. Just as 'Hawai' $\mathrm{i}$ was commonly elided with other Pacific Islands sounds and dances' (Connell and Gibson 2008: 64), outsider perceptions also elided Tahiti with the images and sounds of Hawai' $i$, applying the 'hula girl' persona to the Pacific in general. This double legacy of initial colonial impression (sexual freedom, welcoming natives, uncomplicated life) trailed by notions of commodified difference authored elsewhere (the objectified Polynesian woman whose sensual performance is viewed for money and whose body is showcased for the pleasure of others) means that Tahitian dancers who work in tourism confront and must negotiate the exoticised, often sexualised images that shape tourist expectations of the vahine, the Tahitian woman.

Tahitian cultural activist Turo Raapoto references the violence of such insidious representations for the embattled culture envisaged from the exterior and is explicit in his disdain for the portrayal of his country as the 'whore of the Pacific':

Tahiti is an exotic product made by the Western world for the consumption of their fellow-countrymen ...

Yesterday the Good Savage, today Tahiti is first of all a nice butt, and if you're chaste, you'll speak of the lovely smile of the toothless vahine. The product 'Tahiti', which the Bureau of Tourism sells to the world, isn't it a place of prostitution, where the women are easy and cost nothing? We cost nothing, we have no price, we hardly even exist. (Raapoto 1988: 3)

12 See Kahn's (2011a: 79-83) detailed examination of the postcard and its use in developing and solidifying images of Tahiti. 
10. TOURISTIC ENCOUNTERS

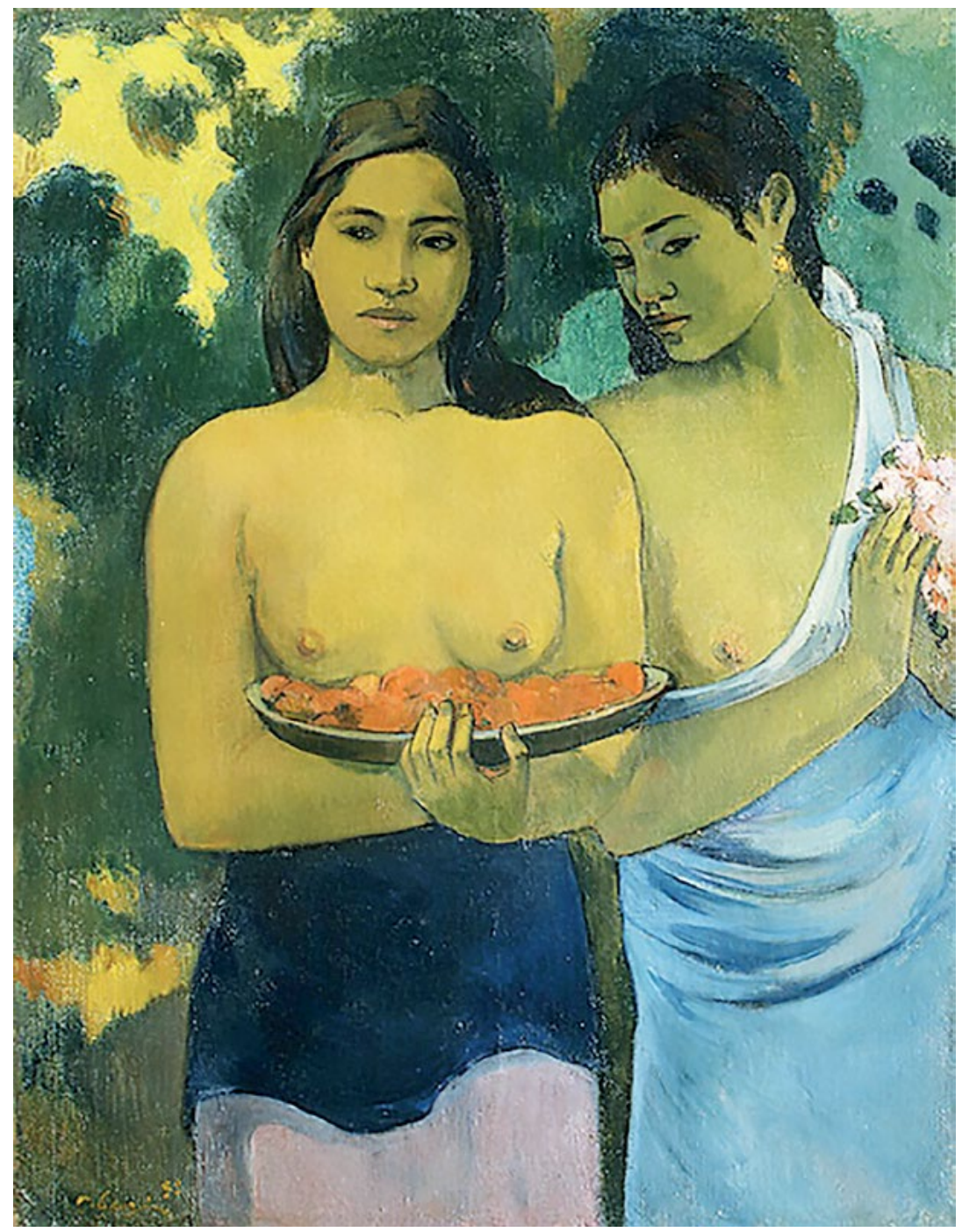

Figure 1. Two Tahitian Women (1899)

Source: By Paul Gauguin (Metropolitan Museum of Art 2000-2017) 
A DISTINCTIVE VOICE IN THE ANTIPODES

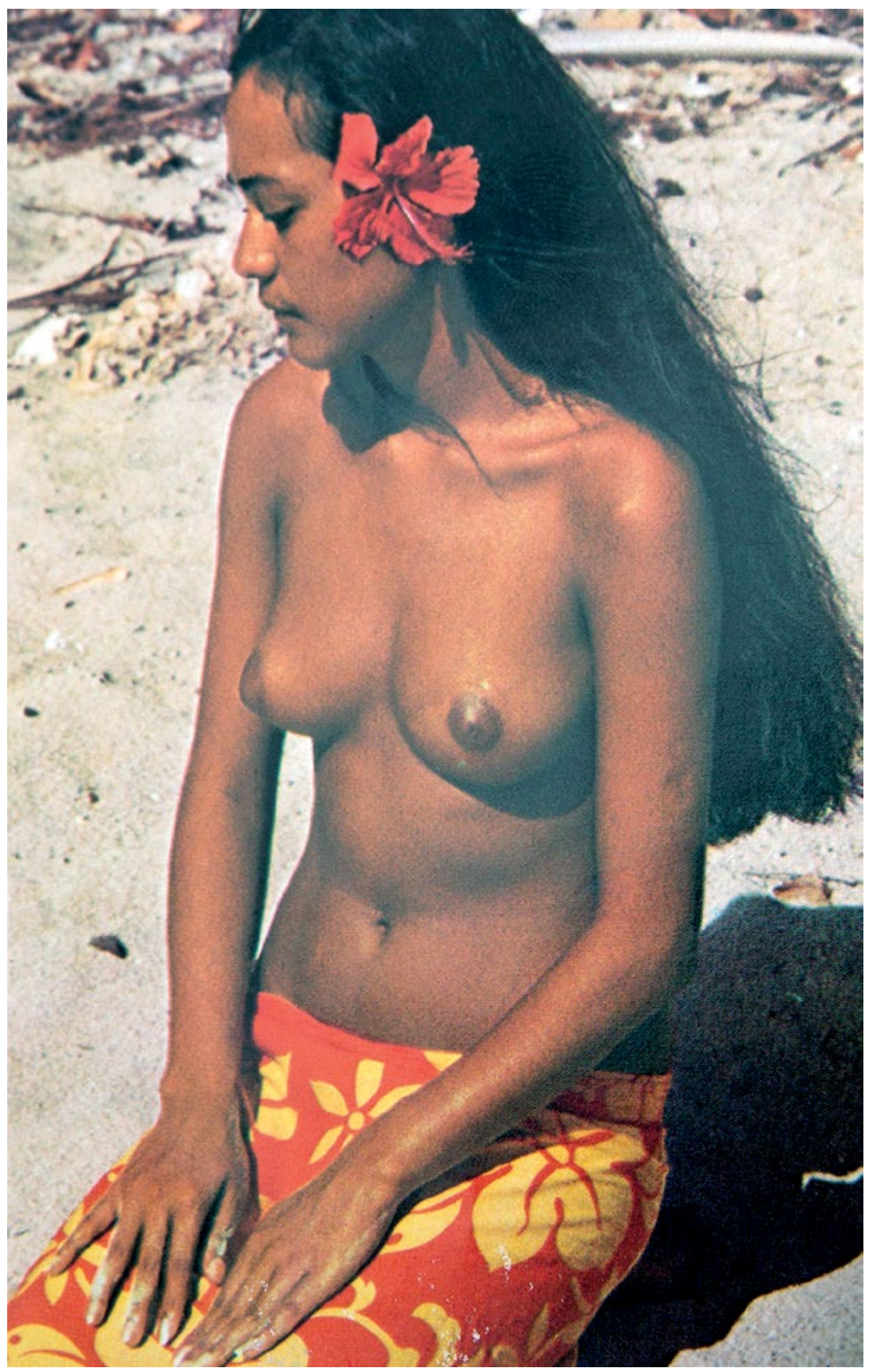

Figure 2. Portrayal of the vahine in 1976

Source: Taken from Putigny (1976: 59), courtesy of Hachette Pacifique 
This eroticised view of Tahitian women impacts music and dance when tourists, consciously or not, transfer this legacy to the female members of the troupe. With such focus on the women, it is little wonder that outsiders have their own heritage of overlooking or dismissing the contributions of male dancers.

The industry's stated desire for a 'nouvelle image' has existed since at least 2001 (Kahn 2011a: 113). Jacqui Drollet, vice president of Tahiti's Ministry of Tourism, Economy, Finance, Budget, and Communication, invoked similar rhetoric in 2005, addressing local tourism personnel by drawing attention to

our first trump card: hospitality and welcome. It is our specialty, that which built the legend of Tahiti ... It encompasses the values of tradition, of sharing, or culture that we want to bring to light, a supplemental springboard to develop further our first source of revenue. (Drollet 2005)

In truth, it was less a 'new' image than a move to remould older portrayals by decentring the myth of the vahine and moving away from the nondistinctive coconut tree-framed beach typical of many destinations. Kahn mentions a redundancy in the chosen imagery (2011a: 113), but a subtle change is nevertheless apparent. In the 2006 brochure distributed by Tahiti Tourisme, ${ }^{13}$ the vahine with her long hair, crown of flowers, tanned skin, and simple parreu dress ${ }^{14}$ is the ubiquitous first-page draw, the feminised image underscored with a brochure title of Tahiti and Her Islands (Figure 3), and she appears immediately thereafter presenting a garland to a man as the eternally welcoming native (Figure 4). In this case, however, the vahine-male contact is foregrounded as safe interaction that transpires under the approving smile of the man's female partner. Shortly thereafter, the vahine appears as a dancing figure dressed entirely in leaves and flowers (Figure 5), accompanied by a description of islands that are 'savage but never hostile' (GIE Tahiti Tourisme 2006). The vahine in this brochure, however, is wearing considerably more clothing than her older sisters, and quickly the images move past the vahine as traditional 'lure' to highlight nature - the beauty of Tahiti, adventures in the mountains or sea, the promise of a haven removed from the stress of urban living (Figure 6). ${ }^{15}$

13 Kahn (2011a: 105-9) discusses the variety of materials developed for different segments of Tahiti's market.

14 The päreu, a simple cloth 2 metres in length, is tied in various ways to make clothing and dance costumes.

15 Reconfiguration of the vahine, together with emphasis on the couple and the highlighting of nature, remains apparent in Tahiti Tourisme's 2014-15 brochure (GIE Tahiti Tourisme 2014). 


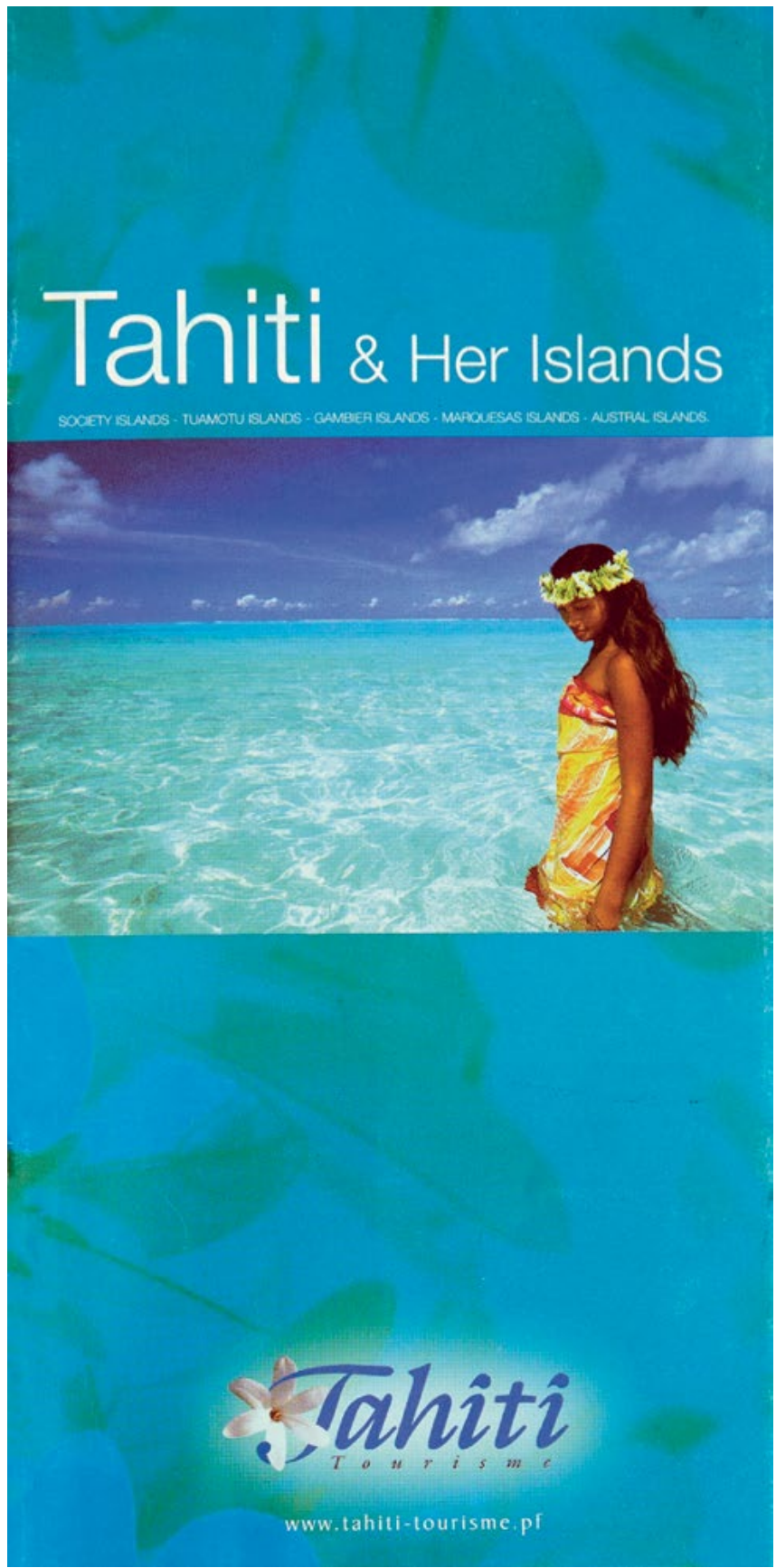

Figure 3. Front page of the official Tahiti Tourisme travel brochure Source: GIE Tahiti Tourisme (2006), courtesy of Tahiti Tourisme 


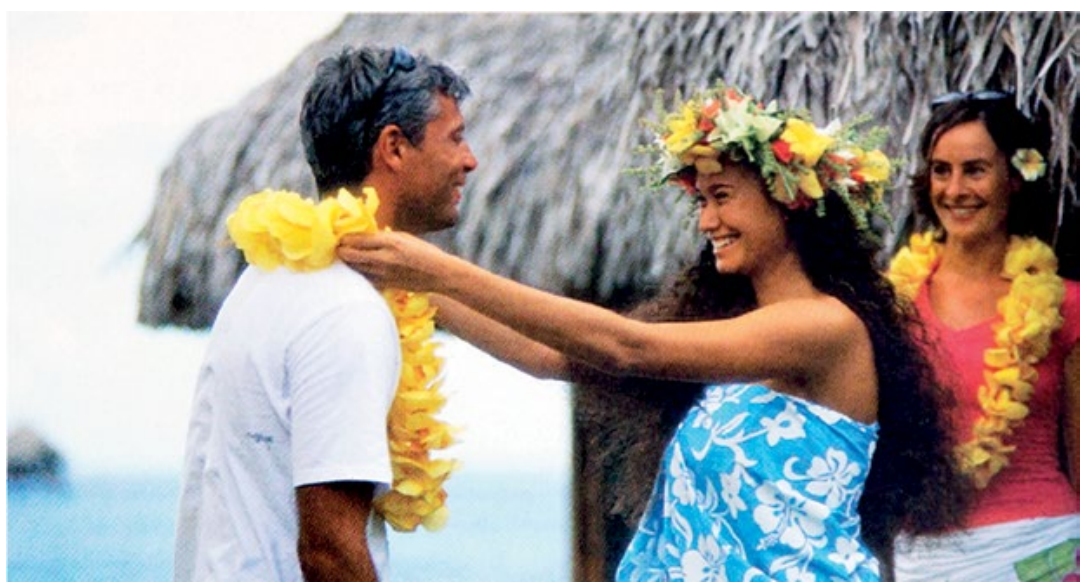

Figure 4. The welcoming native

Source: GIE Tahiti Tourisme (2006), courtesy of Tahiti Tourisme

Tahiti, Moorea, and Bora Bora are high and mystical islands with deep valleys perfumed by the tiare (Tahitian flower), short-lived jewels that one wears over the ear on verdant pathways. Rangiroa, Manihi, Fakarava, Tikehau - atolls at the end of the world, these "pearl islands" enclose in their jewelry-box lagoons the blue depths where black pearls grow and develop.

From the north to the south, from the fertile plains of the Australs to the sharp cliffs of the Marquesas, these fragrant paradises combine all the different landscapes created by generous Mother Nature. Secret or rebellious, savage but never hostile, their beaches, shaded by coconut trees, tell of the centuries of erosion

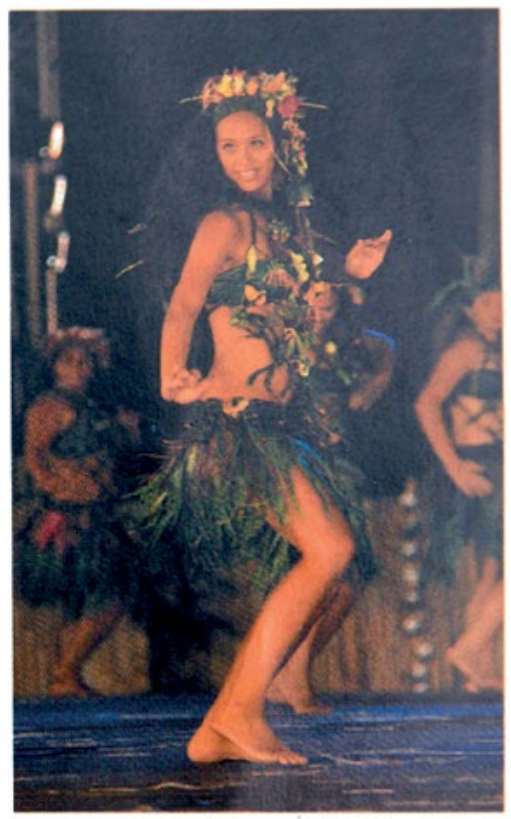

Figure 5. The dancing nature figure

Source: GIE Tahiti Tourisme (2006), courtesy of Tahiti Tourisme 


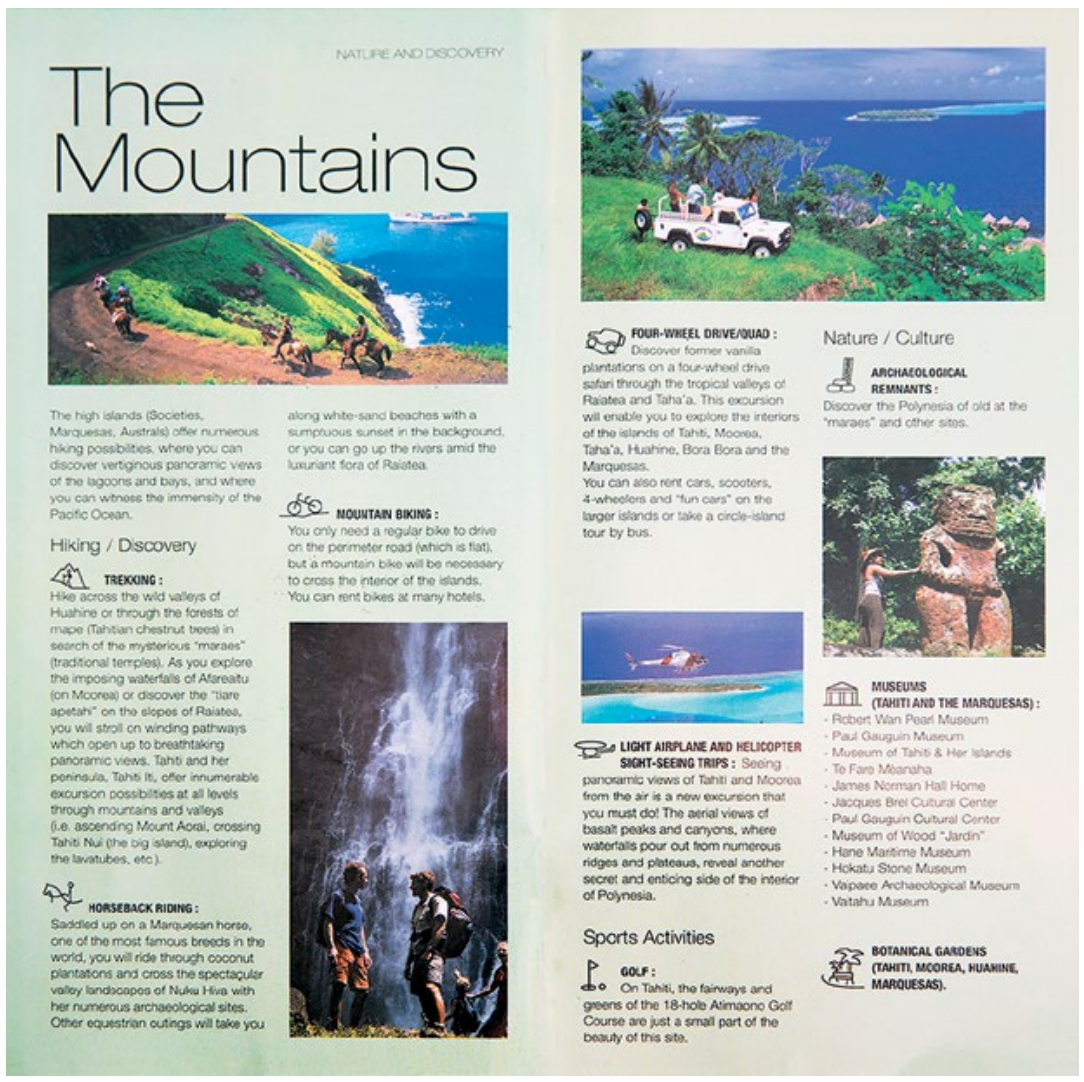

Figure 6 . The beauty of nature

Source: GIE Tahiti Tourisme (2006), courtesy of Tahiti Tourisme

Both the vahine image and the promotion of Tahiti as a natural paradise are market strategies that invoke centuries-old portrayals of the islands-drawing on the legacy for its recognition value, but shaping it in distinctive ways. New efforts remove the vahine from the sexualised frame of irresistible siren calling to a single, invariably white, male and recast her as the charming greeter of a heterosexual couple. Similarly, subtle differences in the modern remaking of images as marketing ploy highlight nature not only as virgin landscape but as a playground for experiences (Figure 6). No longer backdrop to a pristine beach, the ocean now offers the adventure of sailing or deep-sea diving. The mountains are not merely unspoiled land, they are meant to be actively explored and experientially claimed - the pictured $4 \times 4$ underscoring the 'off the beaten track' motif, but staging the whole as accessible. Bringing to mind Barnet and Cavanagh's concept of the 'Global Cultural Bazaar' (1995: 15) 
as a market where ideas and imaginings, cultural constructions, and lifestyles are promoted and consumed, Tahiti has set up its stall in the bazaar not as a place to find a woman, but to experience adventure and what it takes to be happy in a natural, welcoming environment.

Music and dance support that packaging of Tahiti as natural paradise when configured as part of a simple life, where everyone 'naturally' sings and dances with unrestrained time to do so. Amadine Prévost, sales and marketing assistant at the Intercontinental Hotel Tahiti, espoused this romanticised view of music and dance:

Once here they [the tourists] realize that everyone dances and that it is really something natural ... Everybody does it so well that there is not this professionalism that we are expecting because it is not an elite that dances. It's everyone. (interview, 23 June 2006)

Such packaging of the arts obscures the artistic reality of contemporary French Polynesia and belies the many years of training and long hours of rehearsal required of Tahitian performers. It provides a glimpse into how performative arts fit into the larger goals of the industry, but also demonstrates tourism's continued potential to weave the arts into unrealistic narratives serving touristic purposes. The needs of tourist marketing, however, interact with the arts in less insidious ways when tourism's attempt to disturb the vabine myth and to foreground nature happens to align with changes occurring in Tahiti's performing arts. Neither is the direct cause of the other; rather, a fortuitous meeting supports both.

\section{Marketing difference: Images in flux}

Tourism in Tahiti may be altering the image of what it offers visitors, but the marketing thrust resides firmly in one underlying theme: Tahiti is selling difference-as the exotic. A conversation with Karine Villa, director of operations for Tahiti Tourisme, reveals how performance is part of that difference:

The culture of Polynesia is the important vector for tourism because this is where Tahiti is truly different... The role of dance in portraying this culture is vastly important, because dance involves so much more than merely movements. There is the sculpting of the drums, the music, the costumes, the use of vegetal resources, the world of flowers. The artistic aspects are visual and strong in that they are unique. (interview, 14 June 2006) 
To Villa's list, I would add the song poetry, the most important aspect from a Polynesian perspective. Although the words are not understandable to most tourists, visitors process them as part of a sensed - not gazedenvironment that attaches directly to place. A marker of Otherness, they transport the experience out of the ordinary. Costumes are remarkable from a tourist perspective, both the characteristic more dance skirt made from bark of the pürau tree (the 'grass' skirt) and the simple päreu wraparound cloth iconised by Gauguin. Dancer attire is especially notable in the ways Tahitians incorporate nature-fashioning shells, mother-ofpearl, feathers, flowers, and various plant parts (including seeds, leaves, roots, and bark) into strikingly beautiful and skilled artistic expressions. Visually and aurally, the performance marks the new and different for the uninitiated.

When dance troupes include almost entirely Polynesian/part-Polynesian performers, as in Tahiti, racial difference becomes part of that visual field as well. Speaking of Hawai $i$, Desmond situates this racialised view for American tourists:

Hawaiians are portrayed as neither black nor white. The importance of this presumed racialization in the visitors' imaginary is that it helps to manufacture and 'authenticate' at the bodily level a sense of 'exotic' difference ... The resulting 'soft primitivism' proffers a gentle, sensuous encounter with difference- different enough to be presented as 'alluring' but not threatening. (Desmond 1997: 88)

Her comments apply equally well to Tahiti (or any Polynesian island). The self-exoticised framing of French Polynesia as a 'savage but not hostile' physical environment (Figure 5) reflects this heritage of soft primitivism - an uneasy reminder of Ra'apoto's claim that Pacific cultures buy into externally created narratives that influence and shape Islander views of themselves.

The display of difference is the crucial underpinning behind the working concepts and actions of Tahiti's tourism officials. In Villa's words, 'there are islands and beautiful beaches all around the world - but only one place that has the culture of Tahiti' (interview, 14 June 2006). Tahiti Tourisme's director Teva Janicaud underscored this at a March 2011 meeting for travel professionals in Paris: 'We have decided to position our communication efforts on Polynesian identity. What makes the difference for Tahiti is the 
welcome, the mode of life, and not just beautiful landscapes' (ATP 2011). Strategic foci outlined for development included niche marketing (diving, sailing, and cruising), audiovisual production, and drawing international attention to large Polynesian events such as the Heiva, the annual national music and dance competitions (ATP 2011).

Culture, identity, way of life-all tie directly to performance, whose aural, visual, and conceptual aspects aid in constructing and bolstering the promotion of Tahiti as a unique destination rich in artistic culture. Music and dance are the entertainment of choice once the visitor has arrived, but Tahiti Tourisme also considers them an essential first contact for tour promoters who organise voyages and a tool for presenting and marketing Tahitian culture at international travel fairs and tourism events abroad. ${ }^{16}$ The foregrounding of performance is well founded. The opening attack of the slit-drums trumpets a performance at such events, drawing people from far corners of the venue (Kahn 2011b: 195), but it is the combination of sonic power with the captivating visuality of the dance, costumes, and physical display that plants the seeds of a desire to discover the islands first-hand.

There is not one specific [dance] group attached to this important governmental department, but rather our function is to help those groups that want to travel. Tahiti Tourisme does not fund the complete travel for groups - rather, we try to help when possible by aligning a group's invitation to events that benefit tourism. In other words, a group will come to us saying, 'Can you help us? We are invited to this festival and need some assistance'. (Villa, interview, 14 June 2006)

In exchange for partial financial support, troupes help out by performing for tourism events, distributing brochures, and assisting with promotions (Villa, interview, 14 June 2006). The interests of tourism and performance are enmeshed. Each needs the other. ${ }^{17}$

16 My focus is on tourism in situ, but performances abroad powerfully frame images of Tahiti when Tahiti Tourisme uses travelling troupes for promotional purposes to establish initial contact with Tahiti (Villa, interview, 14 June 2006).

17 Performance also offers opportunities for young Tahitians to travel and experience the worldin essence, the object of tourism becoming the tourist. One male dancer from the 1970s recounts that repeated tour participation took him to: Italy, France, the United States, New Caledonia, Indonesia, New Guinea, New Zealand, and Australia. Trips lasted as long as four months and could include travel to as many as 30 cities (Mooria, pers. comm., 2015). 
In Tahiti, the needs and goals of tourism in recent years have developed alongside changing internal views of performance, changing the innate binary of tourism/local into a coalesced arena and dialogic site for cultural presentation. On one hand, there is the need of tourism to connect the visitor to the host culture; on the other hand, there are aspects of that ever-changing culture that facilitate chances for a possible alignment.

The tourist industry may package Tahiti as an isolated, natural utopia to get away from it all, but in-country experience affords a human connection for those who desire it - mainly due to both Polynesian hospitality and a tourist desire to 'touch the native culture'. Tahitians have a long-standing tradition of welcoming visitors warmly. In-country government publications appeal to the traditional welcome to induce residents to participate in tourism, creating a positive framing that promotes the direct involvement of locals. ${ }^{18}$ Tahitians are staunchly proud of their homeland and their culture. Through tourism, Tahitians benefit from definite economic advantages, but also receive constant reaffirmation of the presumed superiority of their islands and way of life.

Tourism is presently remoulding the image it presents to these visitors, but an internal shift in how Tahiti views itself, particularly through the dance, actually preceded this refocusing. Forty-five years ago, Tahiti was the vahine. Male dancing at that time was unexciting, it was difficult to find good dancers, and young male dancers often bordered on scrawny. ${ }^{19}$ Given the Tahitian focus of that time on the women and the absence of large numbers of men to establish an equally powerful masculine presence,

18 Tahiti Tourisme encourages citizens to become 'ambassadors' of culture (GIE Tahiti Tourisme n.d.). A government push to promote Islander-run pensions, bringing visitors directly into Tahitian homes and neighbourhoods, is also part of this effort to brand the 'Tahitian welcome'.

19 In the 1970s, Paulette Vienot invited vibrant Cook Island men, with their related but more vigorous dance style lending a note of physical strength and excitement, to tour with her troupe Tahiti Nui (known abroad as the Royal Tahitian Dancers), originally launched as a publicity tool for Vienot's Tahiti Nui Travel agency. Cook Island choreographer Tereapii Enua confirms the Cook Island emphasis on male dancing: 'the men are really the major picture of the dance because the men are energetic and they do a lot of really fast dancing ... they really bring on the tempo!' (The Dance Project 1993: part 2).

The troupe, one of Tahiti's premiere dance groups in the $1970 \mathrm{~s}$, conducted several overseas tours, bringing an especially high level of Tahitian performance to the international stage. It is important to acknowledge the Cook Island contributions to this effort. Many Cook Island pieces entered the repertoire when Vienot invited highly respected Cook Islander dancer/choreographer Turepu Turepu to Tahiti to teach her group new songs and dances for these tours, the resultant programme being a combination of Tahitian and Cook Island repertoire. Three of the Cook Island men remained in Tahiti to dance with Tahiti Nui, whose dancers greatly appreciated and admired the excitement, vitality, and joy these young men brought to performances. 
there is perhaps little wonder that the message that travelled abroad with many of Tahiti's touring groups was a feminised one that reinforced earlier outsider imaging. In contrast, today males have reclaimed their space on the dance floor (Figure 7); the disparity in physique and dance style between them and their predecessors of 40 to 50 years ago is noteworthy.

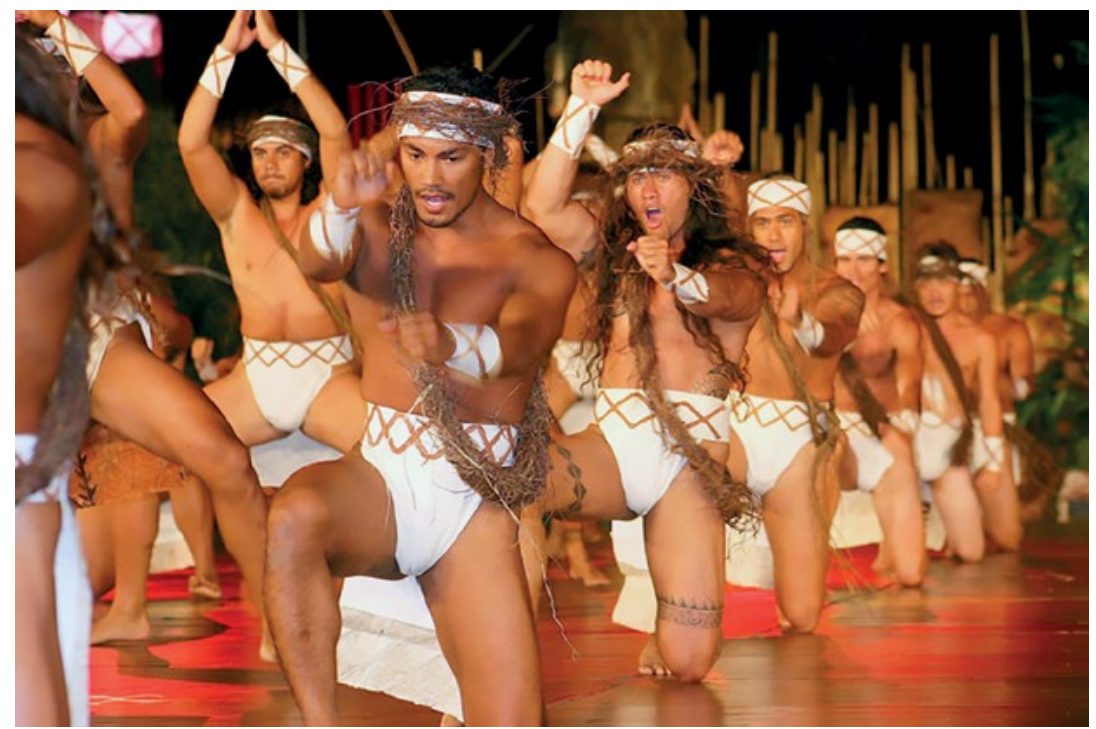

Figure 7. The embodied masculinity of dance-the troupe Hei Tahiti at the Heiva i Tahiti, 2006

The display of masculinity in dance today ties into a current Tahitian male focus on $p \bar{u}^{\prime} a i$ (physical strength), leading to the popularity of power-lifting and body-shaping (Saura 2011: 61), and imbuing today's male dancers with a look that is far from the scrawny teens and young adults of earlier years. Anthropologist Bruno Saura addresses piu'ai on the level of the larger culture, noting that the physical force demonstrated in canoe paddling, rock lifting — and, I would add, dance-is more important for Tahitian men than sports of technique (soccer, karate, boxing) (ibid.: 68-69). He also notes a cult of beauty, strength, and youth in contemporary Tahiti. All of these features align directly with dance (ibid.: 70) and with a practice of corporal display (both male and female) to produce what I view as a cult of the body. 
$P \bar{u}^{\prime} a i$ aligns with another late twentieth- and early twenty-first-century regional development. Across the post-colonial Pacific, Islanders are taking a determined stand in confirming cultural identity and cultural pride that has led to increased displays of strength in dance performances throughout the region. In a remarkable meeting of politics, culture, and the performative arts, 'savage' is the new Pacific cool. In contemporary Tahitian dance, the developed physiques of the men combine with forceful shouts, strong and occasionally aggressive dance gestures and postures, the power of the drums, long hair, extensive tattoos, and minimal costuming that shows off bodies and tattoos to advantage. This is the twenty-first-century Pacific warrior, standing firm and proudly exhibiting his culture while seemingly defiant of Western attempts to make him an imitation of the colonist. This is the 'savage but not hostile' Islander in a zone where politics and culture dance together-an internal remaking of imagery disingenuous to attribute to any tourist influence.

The travel brochure transforms the vahine image and the vahine dancer to diminish her raw sexuality, while a complementary repositioning of male dancers emphasises masculinity. Women no longer dominate the stage, allowing dance a greater equalisation of the sexes. This repositioning redirects the tourist gaze, easing it away from 'sexually available women' to 'beautiful people in nature'. Interestingly, tourism's nature theme ties fortuitously to costuming trends since the 1990s that place high value and aesthetic importance on creative uses of local vegetation..$^{20}$ Reflecting an island world, these amazing costumes (Figure 8) become a virtual stroll through Tahiti's gardens, contributing to the notion of beautiful people living in symbiosis with their environment-the dancing nature figure in the tourist brochure. Importantly, like the empowered masculinity of dance, this trend arose separately from the travel sector as an internal innovative development, even though its fortuitous timing and content allows dance to support governmental efforts to forge a new image for tourism.

20 The annual Heiva dance competitions, for example, now emphasise skill in working with plant materials by requiring groups to include a costume végétal (Moulin 2010: 423). 


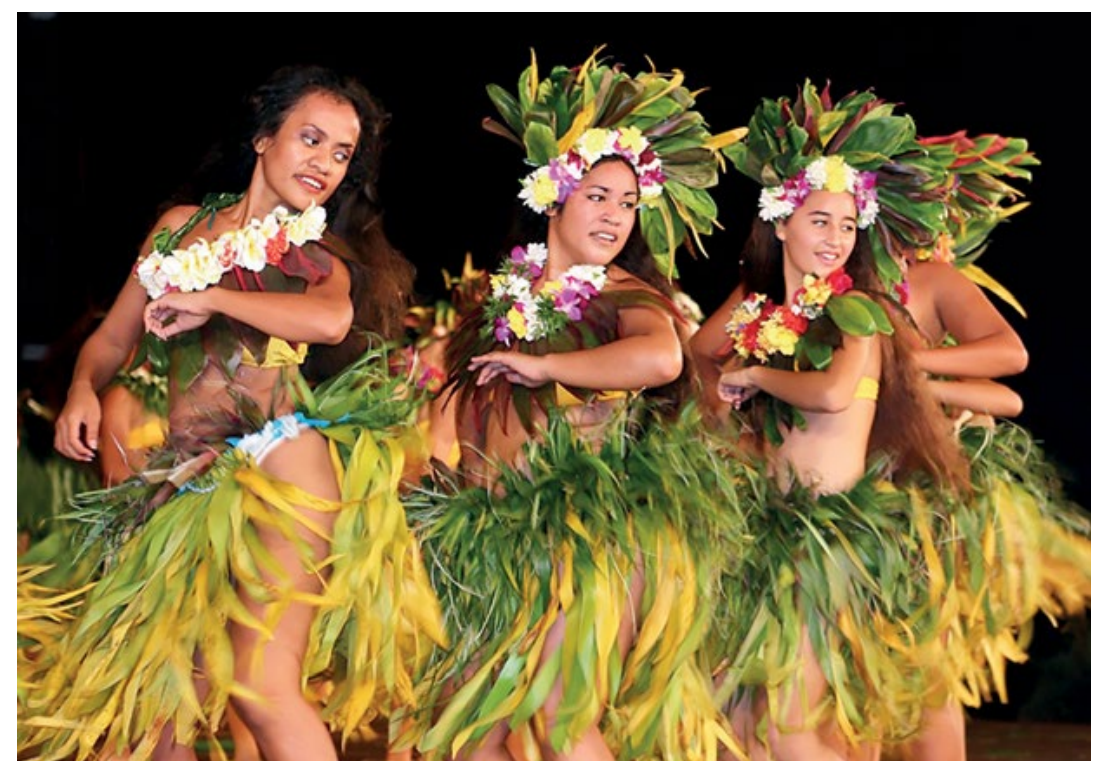

Figure 8. A costume végétal at the Heiva i Tahiti, 2006

\section{Touching a native space}

Heiva, the extended yearly festival taking place in July, is a time for French Polynesians to come together in various organised activities, including several evenings of music and dance competitions. ${ }^{21}$ For performers, the highlight of the year for music and dance calls for carefully researched and prepared costumes, the inspired creativity of a language and culture expert to craft a memorable theme/narrative or song text, extensive choreography for a one-hour presentation, new musical compositions, months of rehearsals absorbing several evenings per week, and groups swelling to 100 or more participants. In short, it contrasts with other occasions and the full range of activities that enliven Tahitian life, from school and church presentations to performances for public events, festivals, travel abroad, fundraisers, balls, official visits, and tourist shows.

In 2006, the deliberate push for increased tourism touched the Heiva, the pinnacle of performance by Tahitians for Tahitians. The visitor centre opened a special exhibit of historic Heiva posters, with the Minister

21 Stevenson (1990) provides extensive discussion of this event. 
of Culture proudly pronouncing the welcome marriage of culture and tourism, and Heiva organisers worked to reserve seats for visitors, making tickets readily available in the hotels and setting up shuttles to take tourists to and from performances. Envisioned as a site for encounter and a place to experience Tahitian culture, the Heiva became a very public arena for displaying hospitality and allowing visitors to easily touch a part of Tahitian culture by rubbing elbows with the Tahitian community. Persuaded that this cultural message passes to tourists, the Tahiti Tourisme official responsible for public relations stated: 'Music and dance are important because to have this contact with Polynesians is crucial' (Tsong, interview, 14 June 2006). Importantly, this contact was on a level determined by Tahitian values, not tourist needs. Absolutely no changes were considered in programme content; announcements were in Tahitian, with some French translation but no English commentary, and without any attempt to 'explain' the culture to outsiders. Tahiti Tourisme, nevertheless, is persuaded that the cultural message passes to tourists and continues pushing for increased cooperation between its office, Heiva organisers, and the hotels. ${ }^{22}$

The tourist can also make very real, but brief, contact with the local at hotel shows. This is encounter through the expressive body, a directness of sensory experience that 'mobilizes bodies, objects, flows, entire landscapes by unhinging potentialities that no one knew were even there' (Saldanha 2005: 717). Most tourists have never seen the dance outside of photographs and filmed representations or heard the live music that accompanies it. Communicated through the bodies of musicians and dancers, the exciting movements, rhythmic drive of thundering drums, and wonderfully perfumed garlands are registered as embodied, felt experience through the eyes, ears, noses, and accelerated heartbeats of the audience. Difference from Western sound and movement systems is part of the interactive space that intensifies the communication. Viewing music

22 Tourism officials bemoan difficulties in marketing the Heiva due to problems in obtaining timely information to distribute to tour promoters for inclusion in their 'added value' marketing (Villa, interview, 14 June 2006). Heiva Nui director Julien Mai noted that Bora Bora, where hotels sponsor the Heiva and provide the prizes, has worked to build the tourist draw over the years (interview, 22 May 2006). In contrast, 2006 was the first year Heiva organisers on Tahiti met with hotel personnel and local tour operators to discuss ticket distribution, agreeing that hotels and tour operators would individually develop publicity and tour packages (Trompette, interview, 22 May 2006).

Underscoring that Tahiti Tourisme makes suggestions but has nothing to do with organisation and production of the Heiva, Villa hopes for increased cooperation and communication. Tahiti Tourisme would feature Heiva events on their website to encourage inclusion in tour operators' value packaging_if provided with early information (Villa, interview, 14 June 2006). 
as an event that 'defines spaces and belongings through the repetition of difference', Saldanha espouses an all-encompassing view of performance as an active and privileged domain of space and difference that stitches together a wide range of elements - body, sensation, money, image, power, nostalgia for the past, and possibilities for the future (ibid.: 718).

Culture analysts tend to denigrate tourist shows, a puzzling situation given dance performance in French Polynesia. Much of this undoubtedly traces to Pacific productions like the commercial Hawaiian $l \bar{u} ' a u$, a feast of traditional food with entertainment catering exclusively to tourists (and rare local residents who accompany visiting friends). In translating unknown music and dance into palatable entertainment for tourists, the $l_{\bar{u}} \mathrm{a} u$ relies on an energetic emcee to bridge gaps between performer and viewer. Desmond (1999: 10-33) provides lengthy analysis of the $\overline{l u}^{\prime} a u$ show as a staged encounter with the consumer-driven goal of attracting the largest possible audiences. In this environment, a varied Pacific-wide repertoire, flashy costuming and programming, food-cost containment, and a high volume of attendees all influence the bottom line.

With its focus on high-end tourism, however, Tahitian hotels avoid the 'pack 'em in' mentality of the Hawaiian $\bar{l}^{\prime}$ 'au, instead presenting Tahitian repertoire in smaller venues offering excellent music and dance, copious fine French and Tahitian cuisine, a stunning physical environment, and a non-mediated performance free of the ubiquitous emcee and tourist hype Desmond describes (ibid.). No effort is made to translate or explain song texts, nor is there any empty attempt to educate the audience. Rather, the feeling is this is the way we enjoy our music and dance. You are welcome, but you are entering our space'.

Although perhaps simply a situation where the 'international tourists' dominant position is not secured in real interaction' (Condevaux 2011:241), I see an additional element at work. At Tahiti's Intercontinental Hotel - a primary venue for music and dance-hotel direction confirmed that 70 per cent of the audience at their three weekly shows is local residents.

These events attract an unimaginable number of locals. The bar is more for the young, but for the Friday and Saturday evening and Sunday morning shows it is families. It is really the outing where everyone is together, and we eat well, and there is a nice show. (Prévost, interview, 26 June 2006) 
Tahiti Tourisme's director of public relations added: 'This is a time for local folks to enjoy a seafood feast or Tahitian food and to get out to see a dance show. Apart from the Heiva, there is not always a lot of opportunity to see good dancing' (Tsong, interview, 14 June 2006). Here, tourism serves local needs in the pluralistic but merged space of the hotel.

The Tahitian habit of reaching out to include onlookers expands the interactive possibilities of this merged space. A standard component of most shows is the 'invitation', wherein dancers select audience members to join them on stage (Figure 9). Kahn reduces this to a photographic moment, saying: 'Dancers were mindful to create memorable experiences and photographic moments for the tourists: and they took care to invite as many guests as possible' (2011b: 203). In doing so she misses important nuances of this practice dating back to the 1950s (Moulin 1979: 51). The 'invitation' serves the dance show on two levels. First is the practical need of providing dancers a momentary pause in a physically demanding programme. Second, the 'invitation' serves as entertainment for the dancers as well as the audience, providing unstructured time in an otherwise highly structured event. The dancer, never knowing quite what to expect from the invitee, must respond on the spur of the moment to the situation-whether it is a partner who unwittingly, but humorously for Tahitians, assumes the opposite gender role; is either very shy or somewhat aggressive; or is an experienced dancer who turns the shared moment into one of admired, mutually skilled display. Each dancer plays that moment as she or he sees fit, the performer emerging superior as either the 'pro' in an unmatched pair or the perfect partner joining a skilled invitee. Local people may dance if asked, and many enjoy this. The real prize, however, is the oblivious tourist—unaware that this seemingly kind invitation will morph from having fun to poking fun.

In the 'invitation', the tourist-no matter how rich, powerful, or entitled-is quickly reduced to an object of good-natured laughter as Tahitians highlight the visitor's inability to do something as simple as dance. Perhaps the tourist has failed to notice the important differences in male/female movements or is awkward and stiff. The humour is especially pronounced for Tahitians, who associate good dancing with skilled lovemaking, the inept tourist coming across as incapable of either. But undoubtedly the tourist's companion has captured the interaction on film, replacing any loss of dignity with durable proof of the encounter and the adventure of having entered a Tahitian space. 


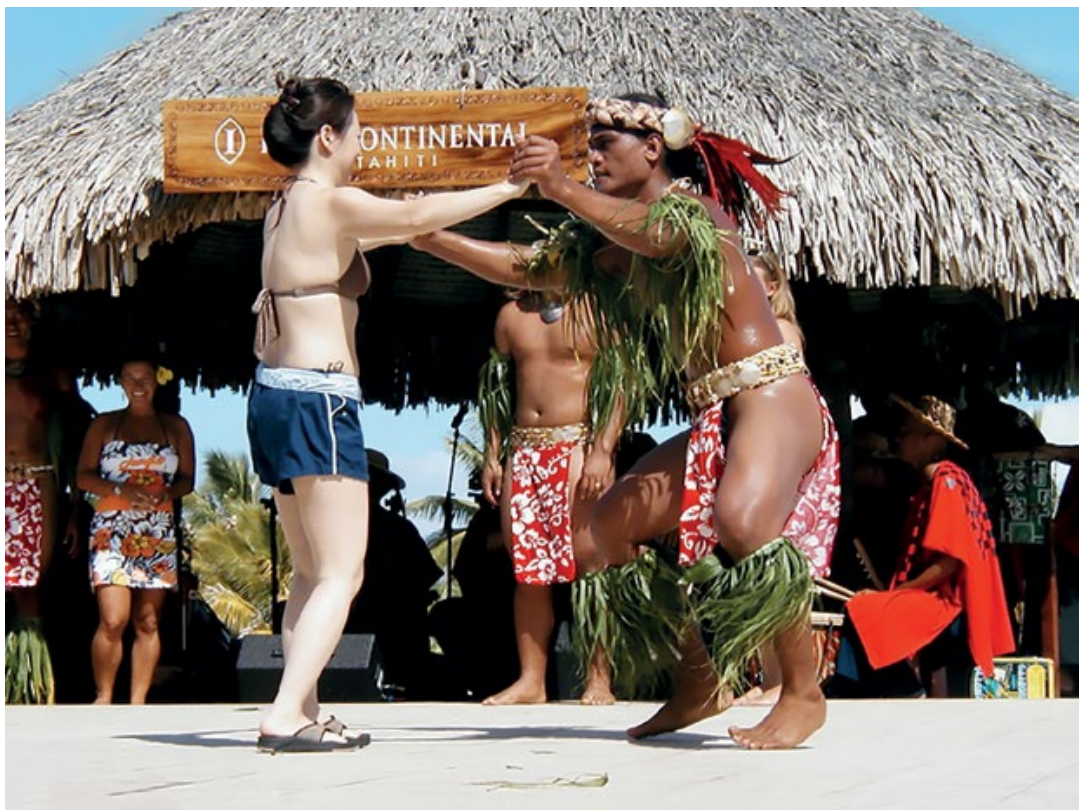

Figure 9. A Japanese tourist becomes part of the 'invitation' portion of the dance show at the Intercontinental Hotel Tahiti, 2006

Scholars have theorised humour as a useful tool in both resistance to tourism and in re-establishing the nexus of power. Condevaux states 'humor, in particular, is a way of coming to terms with the hegemonic dimensions of tourism' (2011: 224), and Gibson discusses 'using concepts of embodiment and affect to trace an anatomy of power in the spaces of tourism encounter' (2010: 525). Authors such as Alexeyeff (2008: 78-79) and Mageo (2008: 74) expand this further, identifying mockery and ridicule as devices for challenging stereotypes that inform many tourist experiences. While the 'invitation' definitely contains elements of performer control and dominance, it is doubtful most Tahitian dancers view this as reclaiming their power as a visited and imagined people. Moreover, although it is humorous to see tourists making fools of themselves, performers would laugh as heartily at any Tahitian who danced poorly or inappropriately, making this moment of humour function in a different space from only that of resistance.

The 'invitation' is an occasion to share the pleasure of dance. It can stop there or push into the realm of humour and teasing, but part of the fun is in the unforeseen possibilities — anticipating the unknown nature of what 
the encounter might bring, but also facing whatever happens while displaying the stage presence and flexibility to 'work' the moment for the enjoyment of audience and fellow performers. Gibson (2010: 525) says, 'something needs to be said about the possibility of reclaiming tourism as fun'. The 'invitation' brings the element of laughter to the encounter, uniting audience and performers in the light-hearted interaction of play.

Embodied interaction also takes place elsewhere in the created spaces of tourism. Kelly Terorotua, dancer in the acclaimed troupe O Tahiti E, developed an innovative way to promote appreciation of music and dance, allowing tourists to touch culture without reducing it to tourist culture. In 2006, Terorotua launched dance classes for her Tahitian students at the Radisson Hotel, negotiating an agreement wherein the Radisson provided a modern, large, air-conditioned room with plenty of parking (all major challenges for Tahitian dance schools). In exchange, she allowed hotel tourists to attend classes for free, reporting that some returned daily throughout their stay. These invariably female guests really enjoyed the experience of being able to feel the dance in their own bodies, of learning next to local residents, and of feeling welcomed by them (Terorotua, interview, 1 August 2006).

This female interaction with Tahitian culture is important given Pacific travel history. Tourism is a gendered space, and some scholars view travel itself as masculine (Leed 1991: 113). Travel also has a reputation of allowing unbridled freedom and sexual licence, what Leed calls 'the spermatic journey' (ibid.: 217-30). Certainly, South Pacific history is legendised as foreign male meets local female. Today, however, travel is no longer a predominantly male activity. Tahiti is now a major player in the wedding/honeymoon market, ${ }^{23}$ statistics over recent years confirming a balance in visitor numbers by sex and a concentration of tourism in the honeymoon-age sector. At around 30 per cent of the total visitor count, this is a significant part of the market share-one contributing to calls to revamp the vahine and her function within tourism. ${ }^{24}$

23 Efforts to build and strengthen this market paid off in 2014 and 2015, when French Polynesia earned top choice in the Brides Magazine list of best honeymoons: 'we are honored to be recognized by Brides as the world's most romantic destination', stated Jonathan Reap, managing director of Tahiti Tourisme North America (Tahiti Tourisme North America 2015).

24 Statistics document strength in this market segment. In 2001, 16.6 per cent of travel to Tahiti was for honeymoons or weddings. Figures for subsequent two-year intervals show: 2003 (21 per cent); 2005 (32 per cent); 2007 ( 25 per cent); 2009 (32 per cent); 2011 (30 per cent); 2013 (29 per cent) (ISPF 2015b). 
The niche market of wedding tourism prompts the now touted 'Tahitian Wedding'. This romantic-couple package, held at a hotel or special site, promises a 'traditional' wedding complete with priest, translator, six musicians/singers, and 16 dancers (Tahiti Excursions n.d.). A web description from Tiki Village on Tahiti's sister island of Mo'ore'a states:

As the couple arrives, local dancers and musicians line the beach to welcome them ashore. The bride is taken to a grass hut to be prepared for the ceremony, massaged with perfumed coconut oil, and dressed like a Tahitian princess. Meanwhile, the groom is taken by canoe to a small beach where he is tattooed (with removable ink) and dressed like a Tahitian Chief.

The Priest performs the ceremony in Tahitian as women of the village sing moving traditional chants. The newlyweds—now sumptuously covered in perfumed flower leis and garlands--enjoy a dance show in their honor and are invited to join in the dance before embarking on a romantic canoe procession accompanied by the sounds of ukulele and guitar. (Tiki Village 2006)

Striking in this fantasy is the participatory nature of it all, and, notably, the clear re-imaging of the vahine. Here Islander women are no longer the objects of desire; instead, recast as aides in creating the ultimate couple experience, they prepare the bride for her big day. The promotional video (Horton 2012; Tiki Village 2012) shows the Tahitian vahine dancingnot to seduce the male, but to welcome the couple into a Tahitian space with music and dance that are true to Tahitian aesthetics. The dance movements and costuming, performers, and music are not compromised by the setting, but are those found elsewhere. The major departure is the event itself, because most Tahitians neither marry like this nor include choreographed group dance at their wedding celebrations. This is a fabricated, commodified package for outsiders; regarding the art, however, the content of what is delivered and ways the arts are used (to welcome, celebrate, express joy in dancing, provide ambiance) are not antithetical to Tahitian values. Performers, as actors in the narrative, occupy a dual space, crossing back and forth between the reality of performance and fictionalised event, finding spaces that matter to them, and ignoring those that do not touch their lives. Many things may be inauthentic in this fantasyland of tourist make-believe and cultural cross-dressing, but certainly not the music and dance. 
Tourism brings culture to the global market, but Tahitian performers negotiate ways of catering to this market without altering their definitions of their arts. With minimal changes to accompany the venue and requisite time-length of the event, the same programme could be reset at a hotel, a presentation for the governor, or a ball for a local sports team, retaining the basic repertoire, execution, and standards of performance even though the context may be wildly different.

\section{Unpacking the tensions: Tourist performance and performer realities}

Performance requires adapting elements to accommodate the given venue or purpose of the event. Imada, discussing Hawaiian hula dancers at the Columbian Exposition in 1893, strikes a resonance with Tahitian dance today by stressing that repositioned performances do not necessarily create incompatible spaces or practices for performers. 'Their decisions about repertoire and staging suggest the troupe adjusted to the demands of tourist performance while preserving the integrity of the dance' (Imada 2011: 162).

Similarly, Tahitian dance directors are flexible-reducing or expanding dancer/musician ranks and time length given the venue requirements and formality of the occasion. Like their earlier Hawaiian counterparts, they know how to adjust while preserving essential elements. In a practice cautioning against any tendency to view hotel shows in outsider/insider or inauthentic/traditional binaries, Tahitian troupes prepare repertoire to serve multiple events, both local and tourist—resetting, not reinventing, it.

Scholars looking at dance and tourism elsewhere in the Pacific nevertheless question performance integrity, ensnaring all in the perception that the Polynesian dancer is primarily a sexualised object of tourism (Condevaux 2011; Desmond 1999; Imada 2012; Kole 2010). Published research centres on Hawai'i and the widespread 'hula girl' image, but problems occur when transferring this to other Pacific destinations, necessitating an alternative interpretation for Tahiti. 
Somewhere along the global march of mass tourism, commodified performance, the 'hula girl' imaginary, and complex images of the South Seas, the emblematic 'grass skirt' of the Tahitian dancer ${ }^{25}$ was feminised and reduced to an archetypal artefact of Pacific 'hoochy koochy'. In reality, both Tahitian men and women wear the dance skirt, not as something 'sexy' but as a valued piece of attire that beautifies the wearer while amplifying the movements of the dance. Accusing the dancer of wearing this as some form of tourist garb, or as a representation of a pre-contact ethnographic 'Other', ignores the fact that Tahitians selected this apparel over long years of cultural practice because it serves the purposes, visual aesthetic, and practical requirements of the dance.

Similarly, coconut-shell bras are mired in representations created elsewhere. Desmond, speaking of Tahitian dancers in Hawai' $i$, claims these are never found outside the context of the tourist show (1999: 25). In Tahiti, however, this same article has appeared in numerous Heiva and non-tourist performances over the decades, signalling merely a practical, readily available, and inexpensive piece of dance attire.

Raising questions more about the viewer than the viewed, some aim critique at the brevity of costumes, particularly in descriptions of Tahitian dance in Hawai 'i: 'Costumes often bared arms, thighs, and backs' (Desmond 1999: 24) or 'women performers with their scanty dresses, costumes, gestures, and movements partly served to fulfil the erotic, sexual, and sensual dimensions of men's pleasure' (Kole 2010: 188). Kole, in a blatant example of scholarly 'upskirting', even publishes several photos of dancers whose päreu dance skirts have flown up to reveal a panty or an upper thigh (ibid.: 189), thereby engaging in an obvious and offensive academic voyeurism and sexual objectification.

Tahitian dancers do not view what they are doing as sexualised performance. Confident young people, they believe they are demonstrating how well they understand the music, how capably they follow the rhythm and move in ensemble with their colleagues, and how they mastered difficult movement techniques to perform them with ease.

25 The bark-fibre dance skirt is an early twentieth-century addition to Tahitian performances. Appearing in images from the 1920s, one photograph from around 1916 (viewed at the Musé de Tahiti et des Îles) hints at an earlier introduction. The skirt may have been part of the cultural exchange that accompanied Pacific work migration (with the Gilbert Islands as a possible origin) or perhaps it came to Tahiti from Hawai' $\mathrm{i}$, where it was already associated with hula in the 1890s (Imada 2012: 80, 83). 
At times, the divide between performer and outsider (whether tourist or scholar) seems enormous. Desmond (1999: 25) claims 'hips make rapid, isolated, percussive movements or slow grinds. The dance is dramatic and sexualised in the tourist shows, swinging suggestively between frenzy and languor, and highlighting female dancers' and, with the word 'grinds', immediately reduces the performance to the level of a strip show. Kole's suggestion that 'the right hands of the performers were giving a flying kiss whereas the left hands were kept raised on one side in a gesture of warm invitation to be embraced' (Kole 2010: 188) reads more like a nineteenthcentury time capsule than a serious description from 2007.

The dancer who teases with a flirtatious look during a solo is owning the moment during an unstructured, very individualised part of the show. The dancer, male or female, who inserts pronounced pelvic thrusts or rotations in a solo is responding to the informal nature of the hotel show, rather than the tourist setting per se. Far from an objectification or victimisation of the dancer, dancers are exerting and claiming erotic agency, something often uncomfortable to the Western observer. Such moments may also touch on the humour Stevenson refers to as 'sexual banter' (pers. comm., 1989), an accepted part of Tahitian interactions. Performers are not 'coerced into performing an inauthentic role but should rather be seen as sophisticated cultural brokers able to creatively present an image of themselves as Other without selling out their cultures' (Tonnaer, Tamisari, and Venbrux 2010: 7).

On the island of Huahine, Kahn notes that dancers make seamless transitions between 'a rehearsed, photogenic notion of 'culture' presented within a tourist setting, and a fluid, spontaneous living of culture outside it' (2011a: 149). On Tahiti, I believe the transition is aided by the fact that it is precisely not a fictionalised space. Tahitians perform exactly the same repertoire, with the same performers and costumes, for tourists as they do for a local audience that will not tolerate bad performances. Reaching far beyond the usual models of economic or power dynamics that come to mind when thinking of tourism, the hotel show in Tahiti supports - on the level of performance-practices that serve local residents as well as visitors. 


\section{Conclusion}

The current thrusts of tourism in Tahiti-the changing image, the highlighting and valuing of nature, and the foregrounding of performance-may be shaped by touristic needs that appear to be mere continuations of the centuries-old tropes of primitivism and exoticism, but these elements all have another side linking directly to the reality of Tahiti today and to Tahitian views of self. Representative of and emerging from local needs, dance ties to a larger market of consumption that Tahitians use for their own benefit as they determine parameters of performance and creatively engage with modernity. Dancers reinforce and deliver a product that conforms to the desired image for tourism, but retain local agency, local aesthetics, and a Tahitian sense of place and doing that grows out of and respects local practice.

Without a reason and venue for regular performance, any art suffers. Tahitian music and dance are event-driven; they arise from and are breathed full of life in the moment of presentation; they require performance and regularly recurrent occasions in order to survive. ${ }^{26}$ Far from signalling cultural loss, tourist presentations provide a venue to perform on a frequent basis, thereby empowering performers with a way to perfect and perpetuate their art as well as promoting continuity in the performative arts. The merged spaces of Tahiti's touristic shows provide regular performances without a continuous drain on the resources of the community and without creating divisions between tourist music and 'local' music. ${ }^{27}$ With its ever-changing audiences, tourism offers a constant stream of occasions, many more than the local community could support.

In reflecting on my performing experiences in Tahiti, I do not see engagement with tourism as having a negative effect in any way on either my performing experience or artistic life. Instead, regular performances in Tahiti's top hotels offered me the opportunity to refine my dance, to understand intimately the relationships between music and dance

26 Atuona, on the island of Hiva Oa in the Marquesas Islands of French Polynesia, did not have traditional dancing for eight years in the 1970s-80s-simply because there was not an occasion important enough to mobilise all the people and resources of the village (Moulin 1991: 168).

27 Former Cook Islander Prime Minister Sir Thomas Davis speaks out against the notion that hotel dancing transgresses norms or stands out as atypical: "When I was young, we used to go to Tahiti to dance. And the dance at that time was very little different than the dance you see that looks commercialized to you' (The Dance Project 1993: part 2). 
through constantly repeated observations and trials, to travel and see the world, to experience the true emotional high points of performance, and to enjoy countless hours of making music and dancing with the friends and artists I admire-an overall experience echoed repeatedly in conversation with former performers. Cook Islander Gina KeenanWilliam points out the benefits she sees in tourism:

Tourism gives us an excuse to dance. It actually helps to maintain and revive art forms. Now we dance more often. In the past it was only once or twice a year. Dancing for tourists and around the hotels has definitely lifted the standards over the years. (Alexeyeff 2009: 65)

In comments that beg for more exploration of the performer's view, not just in Tahiti but elsewhere, Hawaiian kumu bula (hula master) Vicky Holt Takamine notes about her years dancing in Hawai'i's tourist industry: 'But all the hula we did, it was hula we did in hälau [Hawaiian schools of learning]. Hula was not geared for, contrived for the tastes of the tourist' (Imada 2012: 264). Even in a situation where there is often substantial pressure to 'play to the tourist audience', performers are able to uphold the integrity of the dance and to find meaning and purpose on a cultural and artistic level where tourism does not adversely impact their creative or artistic lives. Indeed, considering the long-term participation of many kumu hula in the visitor industry, scholars might question if current analyses of hula in tourism are unnecessarily limited and if there is a need to look more closely at the details of 'strategic commodification' (ibid.: 262). Imada opens this door, documenting the movement of many performers between tourist sites and the daily world of hula training, competition, and performance (ibid.: 263-65), and recognising performance as adaptive and resilient:

Performers on Vaudeville and world's fair circuits, for instance, practiced strategic commodification ... tourist circuits, far from hastening the demise of hula, also helped to keep hula alive during the past century of colonization ... Rather than altogether rejecting tourism, these performers savvily negotiate the seeming contradiction between Native self-determination and their participation in a market-oriented economy that has commodified their land, bodies, and cultural practices. (Imada 2012: 262)

As a performer-scholar, I am privy to the academic discourse surrounding tourism, but feel the weight of the negativity unleashed on tourism by the academy and recognise an important voice is missing in current debates 
surrounding artistic performance within the largest industry in the Pacific. While I do not dispute the far-ranging economic and social effects of tourist development-nor intend to ignore or diminish the multiple challenges inherent in the sale of culture-I also realise that the decisions and actions of Tahitian artists serve the local community as fully as they serve the tourist and marketing forces that depend on their participation. An honest discussion of the arts merits a non-romanticised look at what is truly happening on the level of performance and, especially, how that aligns with cultural practices informed by other demands and negotiated in other spaces apart from the hotel or cruise ship. Surely the details of performer intent and decision-making deserve room in this exploration and in any combined effort to unveil the core meanings of cultural acts.

The sustainability of music and dance is vital to culture, but assuming a facile, anti-tourism stance obstructs tourism's role in that effort. Similarly, the repeated privileging of audience perception over performer intent clouds what could be new perspectives for observing human adaptability, creativity, and prioritisation amid the challenges of encounter. This is where ethnomusicologists and dance ethnologists need to facilitate communications with musicians and dancers on the artistic level to illuminate those perspectives for wider consideration. Performance is encounter, one calling for musicians and dancers to make appropriate adaptations. Provided that the agency for artistic decisions remains with the community — not as an imposed aesthetic shaped only or primarily by external commercial demands-I believe that tourism can be harnessed to service both Pacific performative arts and the local communities that bring them to life. It can, as in Tahiti, play a definite role in helping to maintain and promote the arts-for all to enjoy.

\section{References cited}

Air Tahiti. n.d. 'History of the Company.' Air Tahiti. Accessed 4 May 2015. www.airtahiti.com/air-tahiti-history.

Alexeyeff, Kalissa. 2009. Dancing from the Heart: Movement, Gender, and Sociality in the Cook Islands. Honolulu: University of Hawai'i Press. doi.org/10.21313/hawaii/9780824832445.001.0001. 
ATP (Agence Tahitienne de Presse). 2011. 'Workshop du GIE Tourisme à Paris: Teva Janicaud mise sur l'identité polynésienne.' Tahitipresse (15 March). Accessed 30 March 2011. tahitipress.pf.

Bachimon, Philippe. 2012. 'Tourist Wastelands in French Polynesia: Examination of a Destination in Crisis and Manner of Resistance to International Tourism.'Via@ (1; 28 September). Accessed 15 January 2015. www.viatourismreview.net/Article9_EN.php.

Balme, Christopher B. 1998. 'Staging the Pacific: Framing Authenticity in Performances for Tourists at the Polynesian Cultural Center.' Theatre Journal 50 (1): 53-70. doi.org/10.1353/tj.1998.0001.

- 2007. Pacific Performances: Theatricality and Cross-Cultural Encounter in the South Seas. New York: Palgrove MacMillan.

Barnet, Richard J., and John Cavanagh. 1995. Global Dreams: Imperial Corporations and the New World Order. New York: Simon and Schuster.

Bruner, Edward M. 2005. Culture on Tour: Ethnographies of Travel. Chicago: University of Chicago Press.

Bunten, Alexis Celeste. 2008. 'Sharing Culture or Selling Out? Developing the Commodified Persona in the Heritage Industry.' American Ethnologist 35 (3): 380-95. doi.org/10.1111/j.1548-1425. 2008.00041.x.

Condevaux, Aurélie. 2011. 'Gender and Power in Tongan Tourist Performances.' Ethnology 50 (3): 223-44.

Connell, John, and Chris Gibson. 2008. “No Passport Necessary”: Music, Record Covers and Vicarious Tourism in Post-war Hawai' 'i.' The Journal of Pacific History 43 (1): 51-75. doi.org/10. 1080/00223340802054628.

Dance Project, The. 1993. Dancing! Sex and Social Dance. Ellen Hovde and Muffie Meyer, directors. W. Long Beach, NJ: WNET Channel 13 and Kultur International Films. Accessed 12 December 2016. www.youtube.com/watch?v=gJ7S3Rskj18.

Danielsson, Bengt. 1988. 'Under a Cloud of Secrecy: The French Nuclear Tests in the Southeastern Pacific.' In French Polynesia, edited by Nancy J. Pollack and Ron Crocombe, 260-74. Suva: Institute of Pacific Studies, University of the South Pacific. 
Danielsson, Marie-Thérèse, and Bengt Danielsson. 1973. Gauguin in Tahiti. Paris: Société des Océanistes.

Desmond, Jane. 1997. 'Invoking "The Native": Body Politics in Contemporary Hawaiian Tourist Shows.' TDR 41 (4): 83-109. doi.org/10.2307/1146662.

—_. 1999. Staging Tourism: Bodies on Display from Waikiki to Sea World. Chicago: University of Chicago Press.

Dick, Thomas. 2014. 'Vanuatu Water Music and the Mwerlap Diaspora: Music, Migration, Tradition and Tourism.' AlterNative: An International Journal of Indigenous Peoples 10 (4): 392-407.

Drollet, Jacques. 2005. 'Discours prononcé par le Vice-Président lors de l'ouverture du séminaires des représentants du GIE Tahiti Tourisme.' GIE Tahiti tourisme (25 October). Accessed on 10 June 2006. www.tahiti-tourisme.pf.

Gibson, Chris. 2010. 'Geographies of Tourism: (Un)ethical Encounters.' Progress in Human Geography 34 (4): 521-27. doi.org/ $10.1177 / 0309132509348688$.

GIE (Groupement d'Intérêt Économique) Tahiti Tourisme. 2006. Tahiti and Her Islands. Pape'ete: GIE Tahiti Tourisme.

—_. 2014. The Islands of Tahiti: Travel Planner 2014-15. Tahiti Editions. Accessed 15 May 2015. editions.tereaia.com/_appels_calameo/2014/ TP_EN/index.htm.

—_. n.d. 'Tous ambassadeurs du tourisme: Les bons réflexes de l'ambassadeur du Fenua.' Fenua practique; GIE Tahiti tourisme. Accessed 10 May 2015. www.tahiti-tourisme.pf/mon-fenua/fenuapractique/tous-ambassadeurs-du-tourisme.

Hamilton, George. 1793. A Voyage round the World, in His Majesty's Frigate Pandora ... London: Berwick.

Hawai'i Tourism Authority. 2012. 2012 Annual Visitor Research Report. Honolulu: Hawai'i Tourism Authority.

Hayward, Philip. 2001. Tide Lines: Music, Tourism, and Cultural Transition in the Whitsunday Islands (and Adjacent Coast). Linsmore, Australia: The Music Archive for the Pacific Press. 
Henningham, Stephen. 1992. France and the South Pacific: A Contemporary History. Sydney: Allen and Unwin.

Horton, Patrick. 2012. 'Tiki Village Wedding/Mariage.' Video clip. Sound by Cédric Leleu. Added 25 July 2012. Accessed 26 January 2015. www.youtube.com/watch?v=iNswCOtzZs8.

Imada, Adria L. 2011. 'Transnational Hula as Colonial Culture.' The Journal of Pacific History 46 (2): 149-76. doi.org/10.1080/00223 344.2011.607260.

- 2012. Aloha America: Hula Circuits through the U.S. Empire. Durham: Duke University Press.

IRD (l'Institut de recherche pour le développement). 2012. 'La perliculture, l'or noir de la Polynésie française?' Fiches d'actualité scientifique (Decembre). Accessed 2 May 2015. www.ird.fr/lamediatheque/publications-scientifiques-et-cartes.

ISPF (Institut de la statistique de la Polynésie Française). 2015a. 'Données détaillés.' Enquête de fréquentation touristique. Accessed 2 May 2015. www.ispf.pf/bases/Tourisme/EFT/Details.aspx.

— 2015b. 'Les publications relatives à la catégorie "tourisme".' Accessed 15 May 2015. www.ispf.pf/Publications.aspx?Categorie= Tourisme\#Note\% 20 mensuelle.

Kaeppler, Adrienne. 1977. 'Polynesian Dance as "Airport Art".' Dance Research Annual 8: 71-84.

Kahn, Miriam. 2000. 'Tahiti Intertwined: Ancestral Land, Tourist Postcard, and Nuclear Test Site.' American Anthropologist 102 (1): 7-26. doi.org/10.1525/aa.2000.102.1.7.

- 2011a. Tahiti beyond the Postcard: Power, Place, and Everyday Life. Seattle: University of Washington Press.

- 2011b. Moving onto the Stage: Tourism and the Transformation of Tahitian Dance. In Changing Contexts, Shifting Meanings: Transformations of Cultural Traditions in Oceania, edited by Hermann Elfriede, 195-208. Honolulu: University of Hawai'i Press. 
Kole, Subir K. 2010. 'Dance, Representation, and Politics of Bodies: "Thick Description" of Tahitian Dance in Hawai'ian [sic] Tourism Industry.' Journal of Tourism and Cultural Change 8 (3): 183-205. doi.org/10.1080/14766825.2010.515989.

Larsen, Jonas, and John Urry. 2011. 'Gazing and Performing.' Environment and Planning D: Society and Space 29: 1110-25. doi.org/10.1068/ $\mathrm{d} 21410$.

Leed, Eric J. 1991. The Mind of the Traveler: From Gilgamesh to Global Tourism. New York: Basic Books.

MacCannell, Dean. 1973. 'Staged Authenticity: Arrangements of Social Space in Tourist Settings.' American Journal of Sociology 79: 589-603. doi.org/10.1086/225585.

Mageo, J. 2008. 'Zones of Ambiguity and Identity Politics in Samoa.' Journal of the Royal Anthropological Institute 14 (1): 61-78. doi.org/10.1111/j.1467-9655.2007.00478.x.

Maoz, Darya. 2006. 'The Mutual Gaze.' Annals of Tourism Research 33 (1): 221-39. doi.org/10.1016/j.annals.2005.10.010.

Metropolitan Museum of Art. 2000-2017. 'Paul Gauguin: Two Tahitian Women.' Heilbrunn Timeline of Art History (December 2008). Accessed 15 May 2015. www.metmuseum.org/toah/works-of-art/49.58.1.

Moulin, Jane Freeman. 1979. The Dance of Tahiti. Pape'ete: Les Éditions du Pacifique/Hachette.

__. 1991. 'He Ko'ina: Music, Dance and Poetry in the Marquesas Islands.' PhD diss., University of California at Santa Barbara.

—— 2010. 'Dance Costumes in French Polynesia.' In Encyclopedia of World Dress and Fashion, Vol. 7: Australia, New Zealand and the Pacific Islands, edited by Margaret Maynard, 419-24. Oxford: Berg Publishers / Oxford International Publishers.

- 2013. 'The Marks of a Sensual Person: Music and Dance Performance in the Marquesas Islands.' In Music and the Art of Seduction, edited by Frank Kouwenhoven and James Kippen, 15-35. Amsterdam: Eburon Publishers Delft. 
Putigny, Bob. 1976. Tahiti and Its Islands. 2nd ed. Pape'ete: Les Éditions du Pacifique.

Raapoto, Turo A. 1988. 'Maohi: On Being Tahitian.' In French Polynesia, edited by Nancy J. Pollack and Ron Crocombe, 3-7. Suva: Institute of Pacific Studies, University of the South Pacific.

Saldanha, Arun. 2005. 'Trance and Visibility at Dawn: Racial Dynamics in Goa’s Rave Scene.' Social \& Cultural Geography 6 (5): 707-21. doi.org/10.1080/14649360500258328.

Saura, Bruno. 2011. Des Tahitiens, des Français: Leurs représentations réciproques aujourd'hui. 2nd ed. Pirae, Tahiti: Au Vent des Îles.

Senft, Gunter. 1999. 'The Presentation of Self in Touristic Encounters: A Case Study from the Trobriand Islands.' Anthropos 94: 21-33.

Smith, Bernard. 1985. European Vision and the South Pacific. 2nd ed. New Haven and London: Yale University Press.

Stanley, David. 2004. South Pacific. Emeryville, CA: Avalon Publishing.

Stevenson, Karen. 1990. "Heiva”: Continuity and Change of a Tahitian Celebration.' The Contemporary Pacific 2 (2): 255-78.

Stillman, Amy K. 1988. 'Images and Realities: Visitors' Responses to Tahitian Music and Dance.' In Come Mek Me Hol'Yu Han': The Impact of Tourism on Traditional Music, edited by Adrienne L. Kaeppler and Olive Lewin, 145-66. Kingston: Jamaica Memory Bank.

Tahiti Excursions. n.d. 'Polynesian Wedding Ceremonies at the Tiki Village Moorea.' Accessed 15 May 2015. www.tahiti-excursions. $\mathrm{com} / \mathrm{en} / \mathrm{moorea}$-tours/83-ceremonie-de-mariage-polynesien-au-tikivillage-de-moorea.html.

Tahiti Tourisme North America. 2015. 'The Islands of Tahiti Named "World's Most Romatic Destination" by Brides.' Accessed 12 December 2016. www.tahiti-tourisme.com/media/pressdetail.asp?id $=85$.

Tatar, Elizabeth. 1987. Strains of Change: The Impact of Tourism on Hawaiian Music. Honolulu: Bishop Museum Press. 
Taylor, John P. 2010. 'Photogenic Authenticity and the Spectacular in Tourism: Experience the Pentecost Gol.' La Ricerca Folklorica 61 (April): 33-40.

Tiki Village. 2006. 'A Marriage Made in Paradise.' Accessed 25 September 2006. www.tikivillage.pf.

—_ 2012. 'Tiki Village Moorea: Mariage Polynésien.' Accessed 19 April 2017. www.youtube.com/watch?v=j11VD9Z7CTk.

Tonnaer, Anke, Franca Tamisari, and Eric Venbrux. 2010. 'Introduction: Performing Cross-cultural Understanding in Pacific Tourism'. La Ricerca Folklorica 61 (April): 3-10.

Urry, John. 1990. The Tourist Gaze. London: SAGE Publication.

Waitt, Gordon, and Michelle Duffy. 2010. 'Listening and Tourism Studies.' Annals of Tourism Research 37 (2): 457-77. doi.org/10.1016/j. annals.2009.10.017.

Wang, Ning. 1999. 'Rethinking Authenticity in Tourism Experience.' Annals of Tourism Research 26 (2): 349-70. doi.org/10.1016/S01607383(98)00103-0.

\section{Interviews and personal communications}

- Mai, Julien. 2006. Interview. Pape'ete, Tahiti. 22 May.

- Mooria, Vavitu. 2015. Email correspondence with the author. 15 April.

- Prévost, Amadine. 2006. Interview. Puna'auia, Tahiti. 23 June.

- Stevenson, Karen. 1989. Pers. comm. Puna'auia, Tahiti.

- Terorotua, Kelly. 2006, Interview. Pirae, Tahiti. 1 August.

- Trompette, Sandrine Tiare. 2006. Interview. Pape'ete, Tahiti. 22 May.

- Tsong, Stéphanie. 2006. Interview. Pape'ete, Tahiti. 14 June.

- Villa, Karine. 2006. Interview. Pape'ete, Tahiti. 14 June. 
This text is taken from A Distinctive Voice in the Antipodes: Essays in Honour of Stephen A. Wild, edited by Kirsty Gillespie, Sally Treloyn and Don Niles, published 2017 by ANU Press, The Australian National University,

Canberra, Australia.

dx.doi.org/10.22459/DVA.07.2017.10 